\title{
DYNAMICS OF MICROALGAL COMMUNITIES IN THE WATER-COLUMN/SEDIMENT INTERFACE OF THE INNER SHELF OFF PARANA STATE, SOUTHERN BRAZIL
}

\author{
Ricardo Luiz Queiroz, Frederico Pereira Brandini \& Franciane Maria Pellizzari \\ Universidade Federal do Paraná -Centro de Estudos do Mar \\ (Av. Beira Mar s/n, Caixa Postal 50002, 83255-000 Pontal do Paraná PR Brazil)
}

\begin{abstract}
A B S T R A C T
The composition and biomass of the microalgal community at the water-column/sediment interface on the continental shelf off Parana State (Brazil) were studied every 2 months during 1999. Samples for cell identification and determination of chlorophyll $a$ were taken from the interface layer and at discrete depths up to $4 \mathrm{~m}$ above the sediment. Results showed a community mainly formed by benthic and planktonic diatoms $>30 \mu \mathrm{m}$, benthic diatoms $<30 \mu \mathrm{m}$ and cyanobacteria. Cell densities were generally higher at the interface layer. Resuspension and sedimentation events seemed to be a paramount factor regulating the composition and biomass of these communities, and affected differently cells of different size classes. Cells $>30 \mu \mathrm{m}$, which accounted for most of the pigment biomass, were resuspended from the interface after turbulent periods, and may take advantage of calm periods to stay and grow at the interface. Small benthic diatoms were more susceptible to windinduced turbulence occurring in higher densities in the water column just above the water-sediment interface. A cyanobacterial bloom (Trichodesmiun) was observed at these bottom layers in the spring-summer periods.
\end{abstract}

\section{R ESUMO}

A composição geral e a biomassa da comunidade microalgal da interface sedimento/água da plataforma do Estado do Paraná (Brasil) foram estudadas em 1999 em relação ao regime de ventos. A cada dois meses foram coletadas amostras para a identificação de organismos e determinação de clorofila $a$, na interface água-sedimento e em profundidades discretas, ao longo da coluna d'água, até $4 \mathrm{~m}$ acima do sedimento. Os resultados obtidos revelaram uma comunidade constituída principalmente por diatomáceas planctônicas e bentônicas maiores que $30 \mu \mathrm{m}$, diatomáceas bentônicas menores que $30 \mu \mathrm{m}$, e cianobactérias coloniais. As densidades celulares foram geralmente mais altas na interface. Eventos de mistura e sedimentação parecem ser determinantes na regulação da composição e biomassa de tais comunidades. Formas menores, mais susceptíveis à turbulência, dominaram a comunidade de água de fundo na maioria das ocasiões, e foram as mais abundantes na interface apenas em períodos de extrema estabilidade. Células maiores, aparentemente contendo a maior parte do pigmento observado, estiveram presentes em números significativos na interface sedimento/água, e foram profundamente afetadas pela competição com cianobactérias. Períodos de turbulência mais intensa causada por ventos podem desestabilizar tal quadro ressuspendendo os organismos.

Descriptors: Microalgae, Sediment-water interface, Continental Shelf, Southeastern Brazil.

Descritores: Microalgas, Interface água-sedimento, Plataforma continental, Região Sueste do Brasil.

\section{INTRODUCTION}

The ecological importance of watercolumn/sediment interactions in shallow-water environments is well recognized. This interface is the setting for many crucial biogeochemical paths, exhibiting complex and highly organized communities, which include a significant number of photosynthesizers. They are able to photosynthesize at low light levels (Blanchard \& Montagna, 1992), taking advantage of the usually higher nutrient concentrations in the sediment. Since biomass may accumulate at this layer, its contribution to the overall system productivity is often significantly higher than the integrated adjacent water-column (Cahoon \& Cooke, 1992, MacIntyre et al., 1996). It is not surprising that they are an important food source for sediment fauna (Blanchard, 1991), for filter-feeders (Baillie \& Welsh, 1980; Varela \& Penas, 1985; Muschenchein \& Newell, 1992), and many estuarine consumers (Peterson \& Howarth, 1987). 
The most common members of such photoautotrophic communities are benthic and planktonic diatoms, cyanobacteria and dinoflagellates (de Jonge, 1985; MacIntyre et al., 1996). Actual species composition is the result of water circulation patterns causing selective resuspension, transport and deposition of cells, in association with physiological adaptations to take advantage of these dynamics (de Jonge, 1985).

Most of the studies support the idea that interactions among many physical variables, e.g. turbulence, sediment characteristics, light availability and temperature are key factors regulating photoautotrophic biomass and productivity (Pinckney \& Zingmark, 1991, 1993; Schreiber \& Pennock, 1995; MacIntyre et al., 1996). Grazing and nutrient availability are not frequently mentioned as regulating factors in these communities. However, studies with benthic microalgae in a NE Gulf of Mexico estuary suggested that these communities may be a significant sink for nitrogen, and may be potentially limited by ammonium availability in the upper layers of the sediment (Queiroz, 2002). Other experiments showed that nutrient addition in the water-column stimulated microphytobenthic productivity (Nilsson \& Sundback, 1991; Nilsson et al., 1991; Sundback \& Snoeijs, 1991), and nitrogen may become limiting due to competition with higher plants, in vegetated habitats (Gargas, 1970; Pinckney \& Zingmark, 1993).

Most of the studies concerning the structure and dynamics of such communities have focused mainly on estuaries, lagoons and some other semienclosed coastal habitats. Few of them were conducted on continental shelves. It has been shown that these sediments have a diverse pool of photosynthetic pigments, including chlorophylls $a, b$ and $c$, fucoxanthin, carotenes, among others (Degens, 1989). Some studies suggest they may sustain significant photosynthetic activity, mainly regulated by turbulence. For example, Cahoon et al. (1990), showed that up to $80 \%$ of the total chlorophyll a present in the North Carolina (USA) shelf ecosystem could be sometimes attributed to benthic microalgae. Studies in the USA performed in shallow-water shelves of Georgia, (Hopkinson et al., 1991) and North Carolina (Cahoon \& Cooke, 1992) have shown benthic productivity may account for 40 to $50 \%$ of total (sediment + water-column) productivity. Usually, benthic microalgal biomass exceeded the integrated phytoplankton biomass by factors of 4-6 on the continental shelf of the South Atlantic Bight (Nelson et al., 1999).

The present study describes variations in the general composition and biomass of the photoautotrophic community at the interface, and in the adjacent water-column on the inner continental shelf off Parana State, South Brazil, during 1999.
This environment is constantly subjected to alternating periods of physical mixing and stratification due to seasonal changes in the hydrographic features (Brandini, 1990). The proposed experimental design allowed us to focus on the community that dwell in the fluid bottom layer, just at the interface between watercolumn and sediment. Our hypothesis was that they are more likely to be affected by turbulence, thus more likely to interact with the overlying water-column, compared to organisms firmly attached to sand grains or inhabiting deeper layers of the sediment. This has been neglected in studies concerning shallow-water shelves.

\section{Material And Methods}

\section{Study Area}

The sampling station $\left(25^{\circ} 44^{\prime} \mathrm{S}, 48^{\circ} 21^{\prime} \mathrm{W}\right)$ was located in the inner continental shelf off Paraná State, South Brazil, over the $20 \mathrm{~m}$ isobath (Fig. 1). This particular site is part of a vast system, known as South Brazilian Bight, which extends from South to Southeast Brazil. Sediments of the area have been characterized as fine to very fine well-sorted quartz sand grains (Pezzuto \& Borzone, 1997; Borzone et al., 1999), with low organic and carbonate contents (Borzone et al., op. cit.).

Shelf waters are formed by the mixing of warm, saline and nutrient-poor Tropical Water from the Brazil Current with coastal waters. The latter present variable but generally lower salinities and higher nutrient contents, due to continental drainage from the nearby estuarine systems of Paranaguá and Guaratuba. The contribution of estuarine water is seasonal, with more significant inputs during summer, due to enhanced rainfall and runnoff. The overall effect is that shelf waters are characterized by temperatures ranging from 20 to $22^{\circ} \mathrm{C}$, salinities ranging from 35 to $36 \mathrm{psu}$, and variable but generally low nutrient concentrations (Brandini, 1990; Fernandes \& Brandini, 2004). Bottom intrusions of colder $\left(<20^{\circ} \mathrm{C}\right)$ and nutrient-rich South Atlantic Central Water have been well documented along the mid and outer-shelf off South and Southeast Brazil during summer (Brandini et al., 1989; Castro Filho \& Miranda, 1998). These intrusions may drive watercolumn stratification (Castro Filho, 1990), nutrient enrichments and phytoplankton growth (Brandini et al., 1989).

\section{Sample collection and processing}

Samples were taken on 24 March, 24 May, 24 July, 22 September, 28 November and 23 December 1999 by SCUBA divers, with the help of a dedicated sampling device which allowed them to take 
samples just in the water-colum sediment interface, with little disturbance (Fig. 2). This consisted of a Plexiglass plate attached to one of the extremities of a PVC core (6 cm diameter). The core was fully inserted into the sediment, thus fixing the base at the interface. A glass funnel had its mouth firmly attached to the base and fitted to the core perimeter. Finally, a $60 \mathrm{~mL}$ syringe connected to the tip of the funnel completed the assemblage. Samples from the fluid layer inside the funnel were carefully withdrawn with the syringe, after the device was fixed at the bottom and let to acclimate for a few seconds. Near the spot where the device was placed, a nylon string attached to a weight on one end and to a floater on the other provided a vertical support for $60 \mathrm{~mL}$ syringes placed at $0.1,0.2$, $0.4,0.6,1.0,2.0,3.0$ and $4.0 \mathrm{~m}$ above the interface, which were used for sampling the water-column.

Samples taken with syringes were brought aboard, and $20 \mathrm{~mL}$ subsamples were fixed with $4 \%$ formalin solution for later cell identification and counting. The remaining $40 \mathrm{~mL}$ were filtered through Whatmann $\mathrm{GF} / \mathrm{C}$ filters for later photosynthetic pigment analysis. Cell counts (Utermöhl 1958) were performed with the use of a Zeiss inverted microscope, and identification was made up to the genus level, whenever possible. Chlorophyll $a$ and phaeopigments were determined from the filters, after $24 \mathrm{~h}$ extraction in $90 \%$ acetone, under low temperature and in the dark (Strickland \& Parsons, 1972), with an 010 AU model Turner fluorometer. Cell and pigment concentrations were expressed on a volume-base unit $\left(\mu \mathrm{g} . \mathrm{L}^{-1}\right)$, even for the interface layer.

Daily averaged wind speed and direction were obtained from the meteorological station (Campbell - CM10 Model) of the Centro de Estudos do Mar of the Federal University of Parana in Pontal do Sul, which is approximately $20 \mathrm{~km}$ away from the sampling site (Fig. 1).

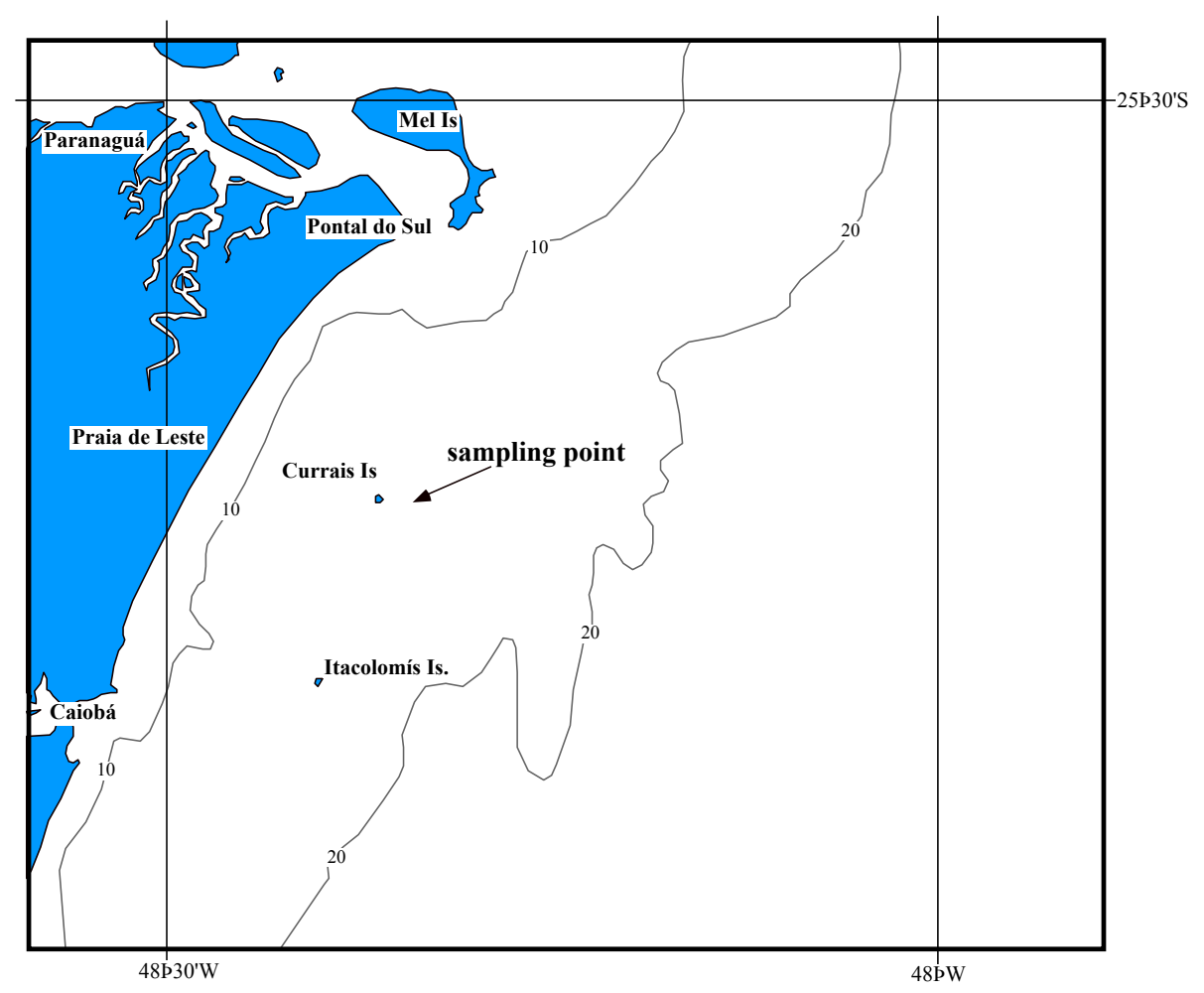

Fig. 1. Map of study area showing sampling station. 


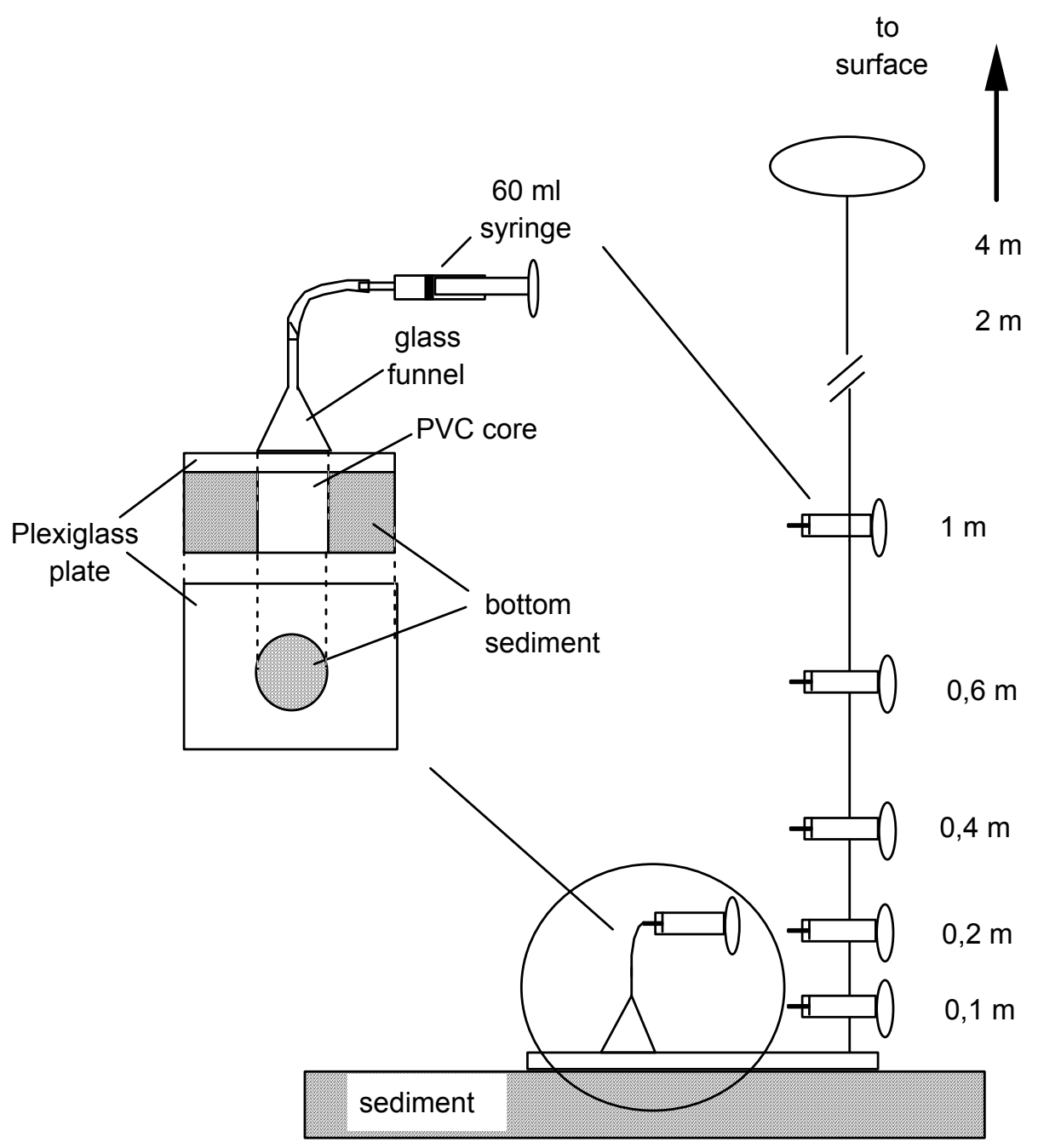

Fig. 2. Schematic representation of in situ collection of microalgae at the water column and water column-sediment interface.

\section{Results}

Microscope examinations (identification and counting) showed that centric and pennate diatoms, along with cyanobacteria, were the most common groups. They were represented by few genera in all sampling occasions. Dinoflagellates were frequent but at such low numbers that they were not considered in the analysis of community dynamics. Silicoflagellates and tintinids were present only in a few samples, and not in all sampled occasions, therefore they were not included in the analysis either.

Due to the importance of size when considering resuspension and deposition events, organisms were separated into two size-classes for analysis purposes: smaller and larger than $30 \mu \mathrm{m}$. Within the $<30 \mu \mathrm{m}$ fraction, the most abundant genera were the pennate diatoms Diploneis, Navicula, Fallacia, and Nitzschia. The $>30 \mu \mathrm{m}$ genera were dominated by the pennate diatoms Thalassiothrix, Navicula, Nitzschia and Pleurosigma, the centric diatoms Coscinodiscus and Thalassiosira, and the cyanobacteria Trichodesmium and Anabaena. Also for analysis purposes, $>30 \mu \mathrm{m}$ diatoms were further classified, according to their occurrence in the environment, into planktonic, benthic and tychopelagic. Diatoms of $<30 \mu \mathrm{m}$ were almost exclusively represented by benthic forms, and referred to as such in the analysis. 
Based on the ecological classification above mentioned, we constructed profiles for organism distributions along the interface and adjacent watercolumn. In general, organisms densities were higher at the interface than in the water-column, but differences between these compartments were variable during the studied period. Two of these profiles are shown in Figures 3a and b, for the most contrasting situations concerning organisms distribution, which happened in July and September. In July (Fig. 3a), organisms were concentrated at the bottom, as opposed to September (Fig. 3b), when they were more evenly distributed along the profile. These contrasting situations motivated us to examine the interface and the adjacent water-column as different compartments, by separate time-series plots. To build these plots we used, for each group, the cell density obtained at the interface, and the average cell density for all sampled depths in the water-column. These plots are shown in Figures 4 (interface layer) and 5 (watercolumn). The same procedure was adopted for chlorophyll $a$ concentrations, which time-series plot for both compartments are shown in Figure 6.

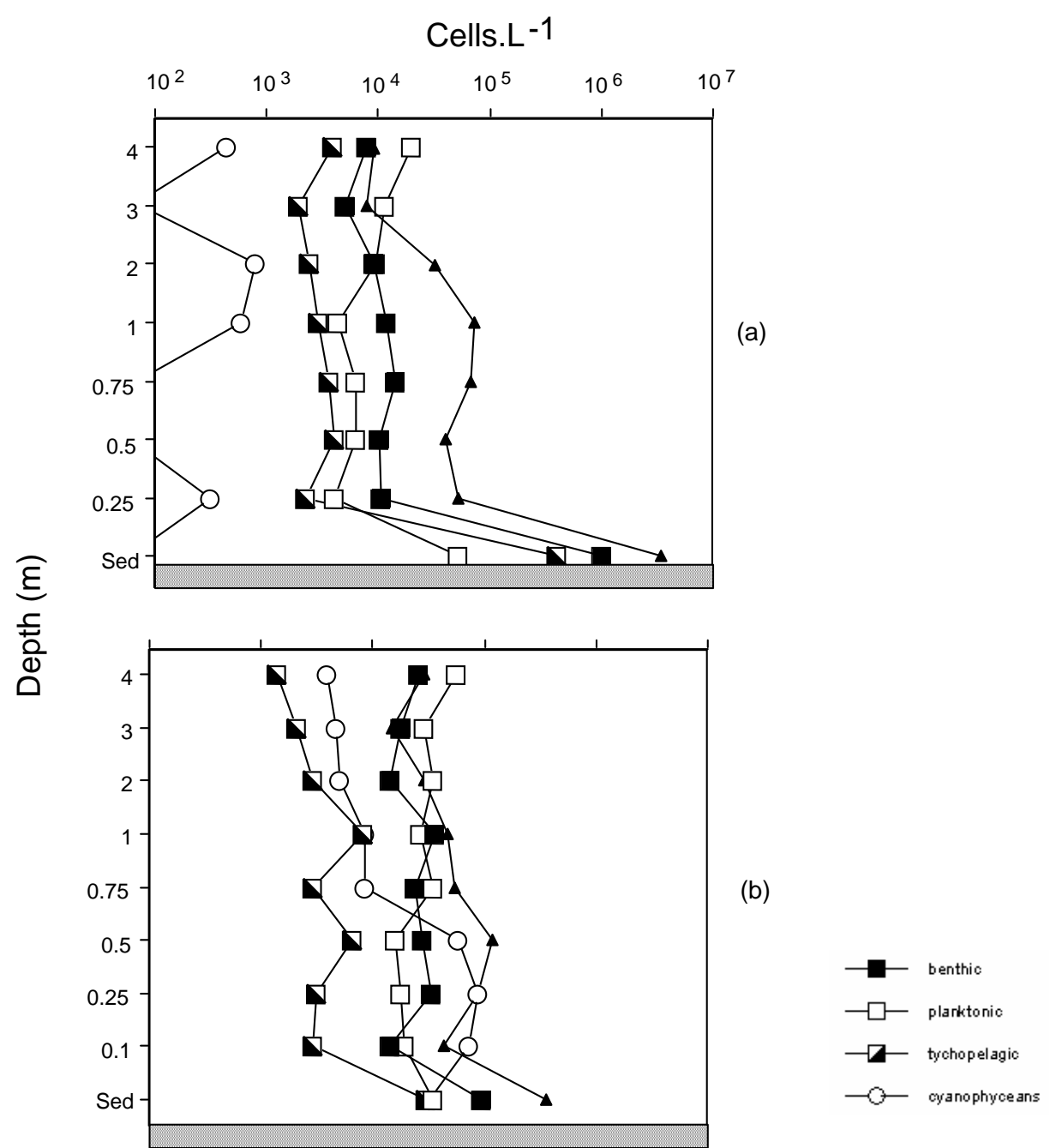

Fig. 3. Vertical distribution of different microalgal groups throughout the water column and water column-sediment interface: (a) in July 1999 and (b) in September 1999. 


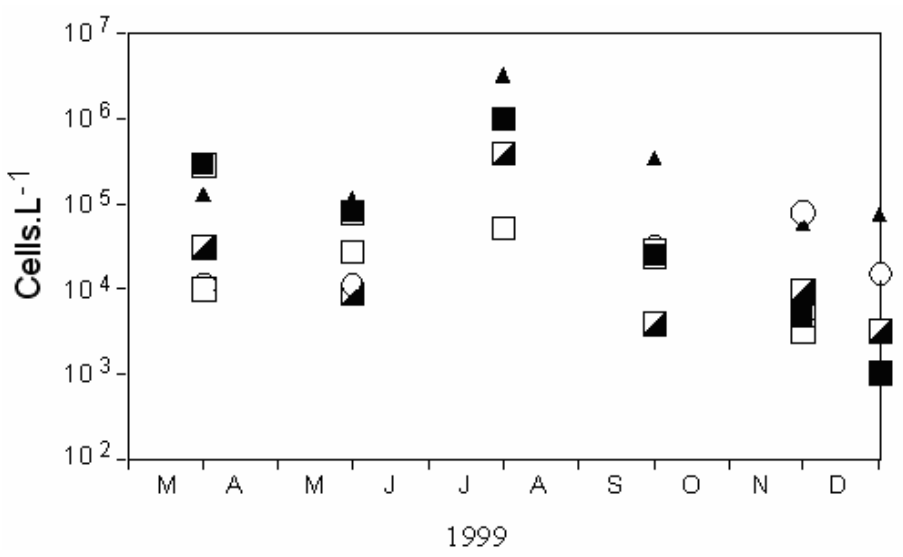

Fig. 4. Temporal variation of cell densities of the different groups in the water column-sediment interface layer. Symbols as in Figure 3.

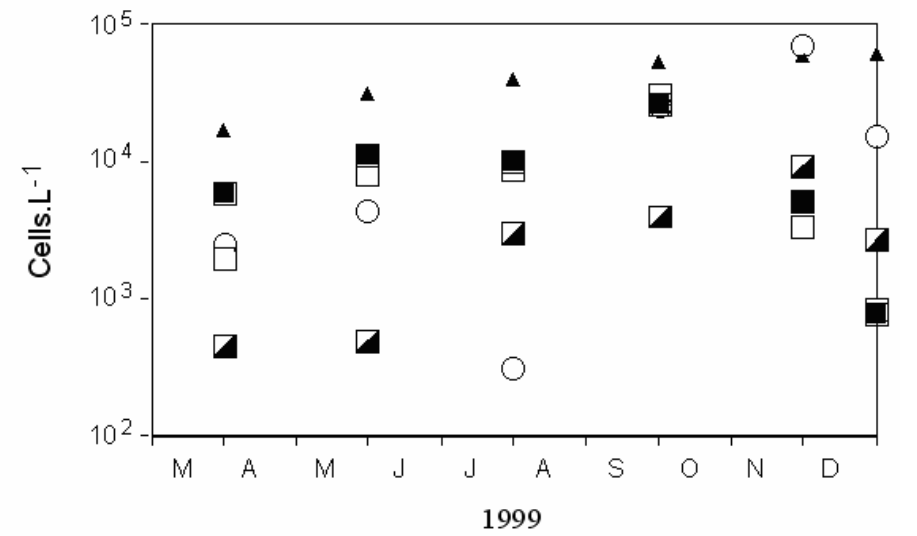

Fig. 5. Temporal variation of average cell densities for different groups in the water-column above the sediment. Symbols as in Figure 3.

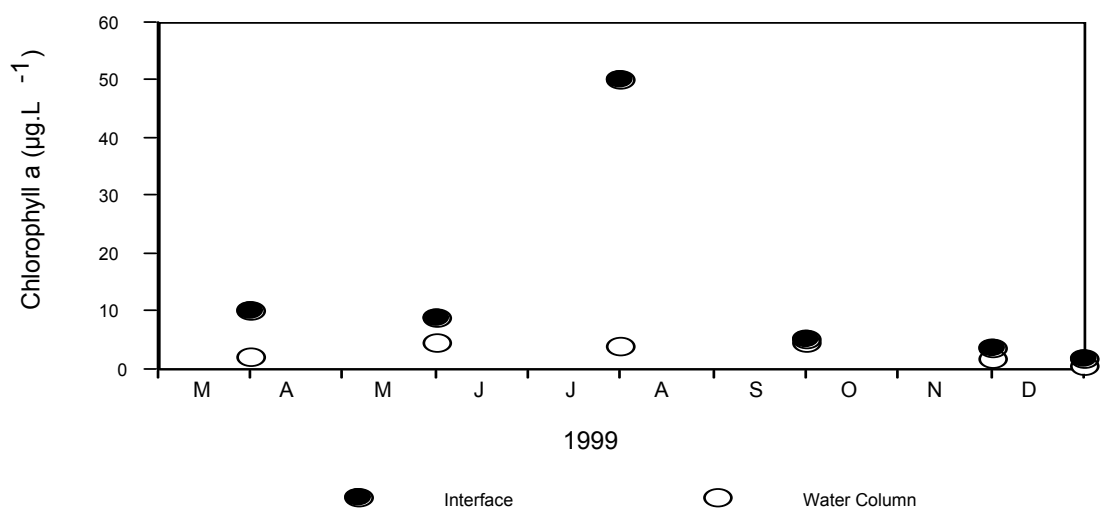

Fig. 6. Temporal variation of average chlorophyll $a$ concentration throughout the water column and water column-sediment interface. Symbols as in Figure 3. 
In March, among organisms $>30 \mu \mathrm{m}$, benthic diatoms were the most abundant at the interface, reaching concentration of $2.9 \times 10^{5}$ cells $\mathrm{L}^{-1}$. Tychopelagic and planktonic diatoms, and cyanobacteria were present at concentrations at least ten times lower than benthic forms. Benthic diatoms $<30 \mu \mathrm{m}$ were also abundant at the interface, with concentrations of $1.3 \times 10^{5}$ cells $\mathrm{L}^{-1}$. In the watercolumn, benthic diatoms $<30 \mu \mathrm{m}$ were the most abundant forms, reaching densities up to $2.7 \times 10^{4}$ cells $\mathrm{L}^{-1}$. Organisms $>30 \mu \mathrm{m}$ were present at lower concentrations in the water-column, and among them, the most abundant were benthic diatoms, with concentrations up to $0.7 \times 10^{4}$ cells $\mathrm{L}^{-1}$.

In May, organism concentrations decreased at the interface (Fig.4). Small and large benthic diatoms were the most important groups in this layer, occurring at similar densities $\left(1.1 \times 10^{5}\right.$ and $0.8 \times 10^{5}$ cells $\mathrm{L}^{-1}$, respectively). On the other hand, cell densities increased in the water-column (Fig. 5). Small benthic diatoms were the most abundant organisms in this compartment (up to $6.2 \times 10^{4}$ cells $\mathrm{L}^{-1}$ ), followed by large benthic (up to $1.6 \times 10^{4}$ cells $\mathrm{L}^{-1}$ ) and planktonic (up to $1.1 \times 10^{4}$ cells $\mathrm{L}^{-1}$ ) diatoms.

In July, organism concentrations at the interface increased at least one order of magnitude, and were the highest recorded during the whole study. Small benthic diatoms were the most abundant group, reaching densities up to $3.4 \times 10^{6}$ cells $\mathrm{L}^{-1}$. Larger diatoms were also present at high concentrations, with benthic diatoms at up to $10^{6}$ cells $\mathrm{L}^{-1}$, and tychopelagic forms up to $0.4 \times 10^{6}$ cells $\mathrm{L}^{-1}$. Cell concentrations remained similar to the ones in May in the water-column. Small benthic diatoms were still the most abundant group (up to $7.210^{4}$ cells $\mathrm{L}^{-1}$ ), and planktonic and benthic diatoms $>30 \mu \mathrm{m}$ reached numbers of, respectively, $2.0 \times 10^{4}$ and $1.4 \times 10^{4}$ cells L $^{-1}$.

In September, cell concentrations at the interface dropped, reaching numbers one order of magnitude lower than the ones observed in July. Small benthic, larger benthic, planktonic and tychopelagic diatoms were present at concentrations of, respectively, $3.5 \times 10^{5}, 0.9 \times 10^{5}, 0.35 \times 10^{5}$ and $0.3 \times 10^{5}$ cells $\mathrm{L}^{-1}$. Trichodesmium colonies were present at significant numbers in this compartment, reaching concentrations of $0.3 \times 10^{5}$ cells $\mathrm{L}^{-1}$. On the other hand, cell densities in the water-column significantly increased in this month. Small benthic diatoms were present at concentrations as high as $1.2 \times 10^{5}$ cells $\mathrm{L}^{-1}$, benthic and planktonic diatoms $>30$ $\mu \mathrm{m}$ reached concentrations of $0.4 \times 10^{5}$ and $0.5 \times 10^{5}$ cells $\mathrm{L}^{-1}$, respectively, and Trichodesmium was present at significant numbers, at up to $0.9 \times 10^{5}$ cells $\mathrm{L}^{-1}$.

In November, the interface layer exhibited a large number of Trichodesmium cells, at concentrations of $2.6 \times 10^{5}$ cells $\mathrm{L}^{-1}$. Small benthic diatoms were also abundant, with concentrations of
$1.4 \times 10^{5}$ cells $\mathrm{L}^{-1}$. Large diatoms exhibited densities at least ten times lower than Trichodesmium and small benthic forms. In the water-column, cyanobacteria were the most abundant organisms, with concentrations up to $1.5 \times 10^{5}$ cells $\mathrm{L}^{-1}$, and small benthic diatoms reached concentrations of $0.9 \times 10^{5}$ cells $\mathrm{L}^{-1}$. Large diatom densities decreased in this compartment, and were one order of magnitude lower than Trichodesmium densities. In December, cell concentrations at the two compartments were the lowest recorded, except for small benthic diatoms. Concentrations of these organisms at the interface were of $5.4 \times 10^{5}$ cells $\mathrm{L}^{-1}$., and in the water-column, they reached densities of $1.6 \times 10^{5}$ cells $\mathrm{L}^{-1}$, being the most abundant group in both compartments.

Chlorophyll $a$ concentrations at the interface were always higher than in the water column except in September, when they were similar (Fig. 6). At the interface, concentrations varied from $50 \mu \mathrm{g} \mathrm{L}^{-1}$ in July, to $1.5 \mu \mathrm{g} \mathrm{L} \mathrm{L}^{-1}$ in December. Chlorophyll $a$ concentrations in this compartment varied from 0.12 $\mu \mathrm{g} \mathrm{L}^{-1}$, in a sample taken $0.6 \mathrm{~m}$ above the interface in December, to $9.23 \mu \mathrm{g} \mathrm{L}^{-1}$, in a sample taken from 0.1 $\mathrm{m}$ above the interface in September. Variations in the average water-column chlorophyll $a$ concentrations may be seen in the time-series plot in Figure 6 .

Southeast winds predominated in the study site throughout 1999. Wind field diagrams prior to selected sampling dates are shown in Figure 7.

The overall composition showed, as expected, a mixed community formed by coastal and oceanic forms. Such community has been reported in the area before (Fernandes \& Brandini, 2004), and the most abundant genera have been already described as being common in similar shelf environments (Krejci \& Lowe, 1987; Cahoon \& Cooke, 1992; Cahoon \& Laws, 1993; Bao et al., 1997; Taylor et al., 1997).

Previous studies in the area reported permanent and homogeneous currents throughout the water-column, driven mainly by tides, with speeds ranging from 20 to $30 \mathrm{~cm} \mathrm{~s}^{-1}$ (Marone et al. 1994, Veiga et al., 2003). These current speeds are well above those needed to cause resuspension in sandy bottoms, as demonstrated by laboratory assays (Grant, 1988), and suggested by sediment characteristics in the area (Pezzuto \& Borzone, 1997; Borzone et al., 1999). Such high-energy conditions most likely reflected on communities structure, since throughout the studied period, small benthic diatoms, for being lighter, seemed to be kept in suspension, and were the most abundant group in the water-column community (Fig. 5). On the other hand, at the interface layer, except for one occasion in July, they occurred at similar densities, or even less abundantly than organisms $>30 \mu \mathrm{m}$ (Fig. 4). Bigger cells are heavier, thus are more susceptible to sink and stay at the bottom in these conditions. 


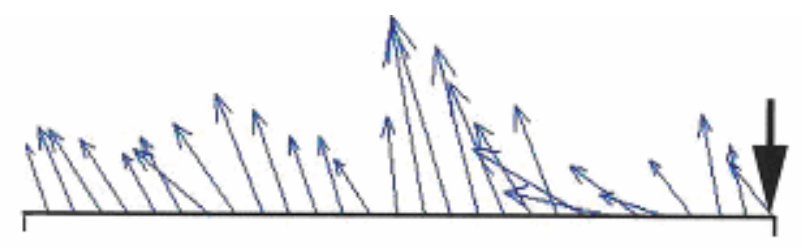

Feb 25

March 24
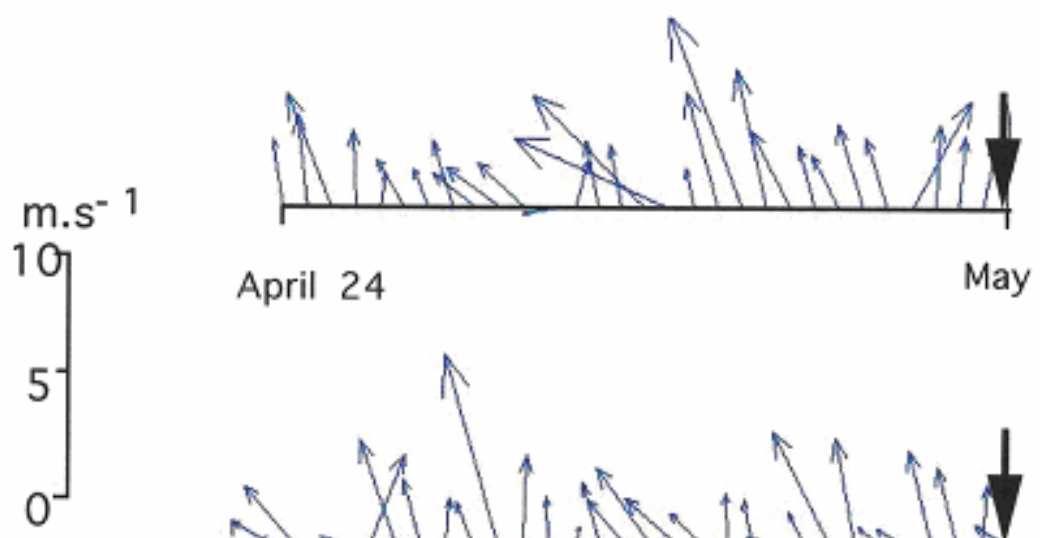

April 24

May 24

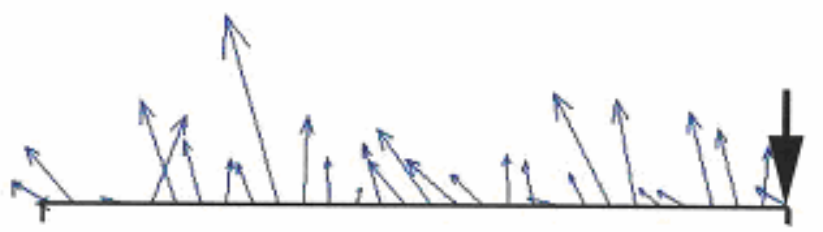

June 25

July 24

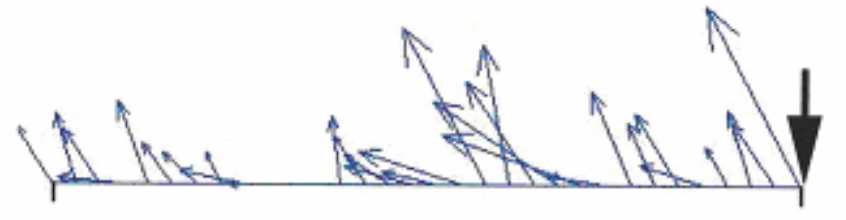

Aug 22

Sept 21

Fig. 7. Wind field prior to selected sampling dates.

\section{Discussion}

The physical forcing in the study area intensifies during the passage of frontal systems, usually characterized by strong southern winds, higher waves, increased turbulence, and meteorological tides (Marone \& Camargo, 1994; Abrahão, 2000). This situation is exemplified in late September, when sampling took place just after a frontal system had hit the region (Fig. 7), causing increased wind speeds, turbulence and water turbidity, as reported by divers. In this occasion, even larger cells seemed to be affected by turbulence. Water-column densities of benthic and planktonic diatoms $>30 \mu \mathrm{m}$ were the highest among all sampled occasions and the density of all organisms at the interface dropped dramatically than the ones observed in the previous July samples. Frontal systems in the area have been associated with decreasing water transparency, increasing water- column chlorophyll $a$ and inorganic nutrient concentrations (Fernandes \& Brandini, 2004; Abrahão, 2000), as well as changes in zooplankton biomass and taxa composition (Abrahão, op. cit.).

In July, there were significant increments of cell densities at the interface. Perhaps the most dramatic event registered during this period was the great increase of small benthic diatoms numbers, which were by far the most abundant organisms in this layer. In contrast to the sampling occasions mentioned above, this situation coincides with an uncommonly long period (from late May to late July, see Fig. 7) of little wind action, if compared to previous sampling occasions. Although we did not measure actual current speeds, this event might have helped alleviate physical stress, and even small cells could stay and grow in the bottom layer. Nevertheless, concentration of cells $<30$ $\mu \mathrm{m}$ in the overlying water kept increasing, which may 
be due to weaker, but still effective background tidal currents.

The overall effect of these deposition/ resuspension processes in this community dynamics may be clearly seen on the obtained vertical profiles of cell densities and chlorophyll $a$ biomass, for the most contrasting situations (Fig. 3). In the unusually calm period in July, when cells concentrated at the bottom, the average organism density and the average chlorophyll $a$ concentration at the interface were, respectively, 78 and 12 times higher than the adjacent water column. In September, after the passage of a cold front, the same ratios were 1.0 and 1.1, respectively.

From September to December, the most significant change in the community composition was the formation of a bloom of the colonial cyanobacteria Trichodesmium. Blooms of this organism at the surface have been traditionally found during springsummer season in the study area (Brandini, 1988; Gianesella-Galvão et al., 1995). In September, colonies were more concentrated at the bottom water $(0,25-0,5 \mathrm{~m}$ above the interface $)$, as can be seen in Figure 3b. This may look unusual, since Trichodesmium colonies have several adaptations (e.g., gas vesicles) that enable them to float. They are commonly found at the surface in open ocean waters (Capone et al., 1997). However, mixing caused by winds may keep colonies at depths of 20 to $40 \mathrm{~m}$ (Capone et al., 1997). These are the depths where we found them during the turbulent sampling date in September. In November, Trichodesmium colonies were the most abundant organisms, occurring at slightly higher numbers than small benthic diatoms in both compartments, and probably outcompeted larger benthic and planktonic diatoms. By the end of December, the bloom had declined considerably. Trichodesmium colonies were at lower densities than November and the number of larger diatoms observed were among the lowest recorded. Small benthic diatoms seemed to be unaffected by the bloom, since they were still present in large numbers at the interface in the water-column.

Some general trends observed for cell densities were confirmed in the chlorophyll $a$ concentration time-series (Fig. 6). Concentrations at the interface were higher than the ones in the watercolumn, particularly for the event characterized in July. However, other trends observed for cell concentrations were not observed in the chlorophyll $a$ concentration time-series. This is particularly evident in November and December, when cyanobacteria and small benthic diatom numbers were the highest, but they were not reflected in chlorophyll $a$ biomass. In order to get insights about these variations, we integrated chlorophyll $a$ values from the interface up to $4 \mathrm{~m}$ above for each sampling occasion (Fig. 8a). As can be seen, cyanobacteria and small benthic diatom numbers did not correspond to integrated chlorophyll $a$ biomass. However, integrated chlorophyll $a$ biomass variations closely resembled the ones observed for the integrated number of larger diatoms, suggesting that most of the pigment content was associated with larger organisms. Regression analysis of integrated chlorophyll $a$ on integrated larger diatom densities based on 6 observations was significant at $p<0,1$, and accounted for $56 \%$ of the variability in integrated chlorophyll $a\left(\mathrm{r}^{2}=0.561\right)$. These results, therefore, suggest that generalizations about community dynamics based only on pigment biomass data must be carefully considered.

The results of this study suggest that, like other shallow-water environments, the photoautotrophic communities of the watercolumn/sediment interface on inner continental shelves are complex. Their composition and biomass seem to be shaped by physical mixing, caused by currents and waves, and they are significantly affected by resuspension and deposition events. These processes determine the vertical distribution of these organisms along the interface and the adjacent water-column profile. It is also suggested that during periods of more stable water-column conditions these organisms seemed to be able to take great advantage from settling down onto (or not being washed away from) high-nutrient sites close to the sediment. Small benthic diatoms, particularly, seemed to be very well-fitted to this environment. They were the most abundant group considering both compartments, they kept increasing in number in the water-column throughout the studied period, and they seemed to be unaffected by competition with bigger organisms. This study also confirms previous observations that small time-scale events (hours to days) are very important in such dynamic environments, and the variability at this time-scale may be as significant as the one observed seasonally (Abrahão, 2000). Further investigations concerning adaptations to take advantage of the nutrient and light gradients to which these communities are exposed during deposition and resuspension cycles would improve our understanding of their role in shallow continental shelf ecology.

\section{ACKNOWLEDGEMENTS}

This work was supported by the Brazilian Ministry of Science and Technology (PADCT IIICIAMB - Process No 620408/98-7). R. Queiroz was suported by a Post-Doc grant from the Brazilian National Council for Scientific and Technological Development (CNPq Grant $\mathrm{N}^{\circ}$ 302099/02-6). We thank two anonymous reviewers, for their helpful insights, and comments on the final manuscript. 


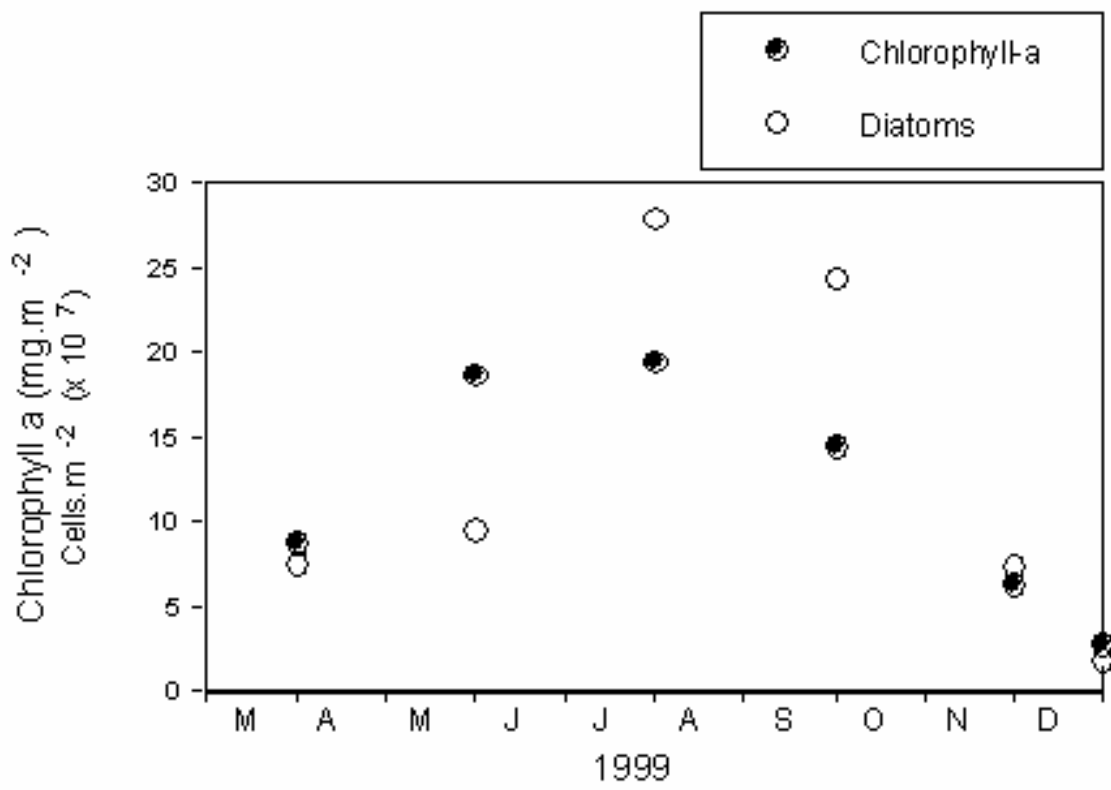

(a)

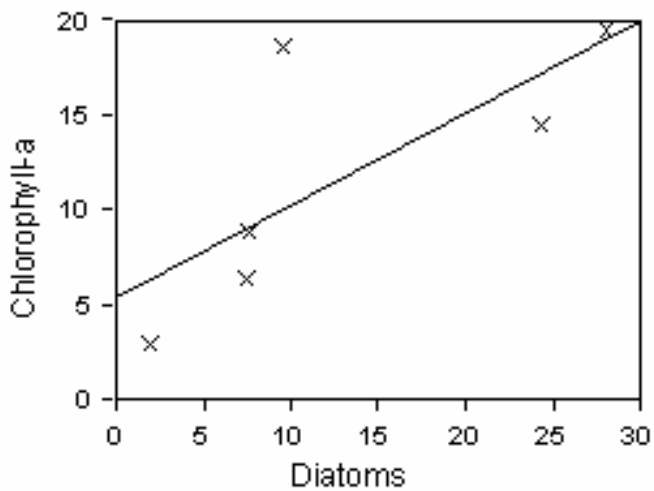

(b)

Fig. 8. Temporal variation of integrated chlorophyll $a$ and integrated large diatoms number (a). Relationship between integrated chlorophyll $a$ and integrated large diatoms number (ILD) over all sampled layers (b). Regression line is Chl $a=0.488 * \operatorname{ILD}+5.360\left(\mathrm{n}=6 ; \mathrm{r}^{2}=0.561\right.$; significant at $\mathrm{p}<0.10)$.

\section{REFERENCES}

Baillie, P. W. \& Welsh, B. L. 1980. The effect of tidal ressuspension on the distribution of intertidal epipelic algae in an estuary. Estuar. Coast. Mar. Sci., 10:165180.

Bao, R.; Varela, M. \& Prego, R. 1997. Mesoscale distribution pattern of diatoms in surface sediments as tracers of coastal upwelling of the Galician shelf (NW Iberian Peninsula). Mar. Geol., 144(1-3):117-130.

Blanchard, G. F. 1991. Measurements of meiofauna grazing rates on microphytobenthos: is primary production a limiting factor? J. Expl. Mar. Biol. Ecol., 147:37-46.
Blanchard, G. F. \& Montagna, P. A. 1992. Photosynthetic response of natural assemblages of marine benthic microalgae to short- and long-term variations of incident irradiance in Baffin Bay, Texas. J. Phycol., 28:7-14.

Borzone, C. A.; Pezzuto, P. R. \& Marone, E. 1999. Oceanographic characteristics of a multi-specific fishing ground of the Central South Brazil Bight. Mar. Ecol., 20 (2):131-146.

Brandini, F. P. 1988. Composição e distribuição do fitoplâncton na Região Sueste e suas relações com as massas d'água (Operação Sueste I - Inverno/ 1982).Ciência \& Cult., 40(4):334-341. 
Brandini, F. P. 1990. Hydrography and characteristics of the phytoplankton in shelf and oceanic waters off Southeastern Brazil during winter (July/ August 1982) and summer (February/March 1984). Hydrobiologia, 196(2):111-148.

Brandini, F. P.; Moraes, C. \& Thamm, C. A. 1989. Shelf break upwelling, subsurface maxima of chlorophyll and nitrite, and vertical distribution of a subtropical nanomicroplankton community off southeastern Brazil. In: F. P. Brandini ed. Memórias do III Encontro Brasileiro de Plâncton. Curitiba, UFPR. p. 47-55.

Cahoon, L. B.; Redman, R. S. \& Tronzo, C. R. 1990. Benthic microalgal biomass in sediments of Onslow Bay, North Carolina. Est. coast. Shelf Sci., 31:805-816.

Cahoon, L. \& Laws, R. 1993. Benthic diatoms from the North Carolina Continental Shelf: Inner and Mid Shelf. J. Phycol., 29:257-263.

Cahoon, L. B. \& Cooke, J. 1992. Benthic microalgal production in Onslow Bay, North Carolina, USA. Mar. Ecol. Prog. Ser., 84:185-196.

Capone, D. G.; Zehr, J. P.; Paerl, H. W.; Bergman, B. \& Carpenter, E. J. 1997. Trichodesmium, a globally significant marine cyanobacterium. Science, 276:12211229.

Carpenter, E. J. 1983. Physiology and ecology of marine planktonic Oscillatoria (Trichodesmium). Mar. Biol. Lett., 4:69-85.

Castro Filho, B. \& Miranda, L. B. 1998. Physical oceanography of the western Atlantic continental shelf located between $4^{\circ} \mathrm{N}$ and $34^{\circ} \mathrm{S}$. In: Robinson A.R. \& Kenneth H. B. eds. The Sea, New York, John Wiley \& Sons, 11:209-251.

Castro Filho, B. M. 1990. Estado atual do conhecimento dos processos físicos das águas da plataforma continental sudeste do Brasil. In: Simpósio de Ecossistemas da costa Sul e Sudeste Brasileira, II. 1990. Anais. Lindóia, São Paulo, ACIESP, 4:1-19.

de Jonge, V. N., 1985. The occurrence of epipsammic diatom populations: A result of interaction between physical sorting of sediment and certain properties of diatom species. Est. coast. Shelf Sci., 21:607-622.

Degens, E. T. 1989. Perspectives on Biogeochemistry. New York, Springer - Verlag. 343p.

Fernandes, L. F. \& Brandini, F. P. 2004. Diatoms associations in shelf waters off Parana State, southern Brazil: annual variation in relation to environmental factors. Braz. J. Oceanogr., 52(1):19-34.

Gargas, E. 1970. Measurements of primary production, dark fixation and vertical distribution of the microphytobenthic algae in the Öresund. Ophelia, 8:231253.

Gianesella-Galvão, S. M. F.; Costa, M. P. F. \& Kutner, M. B. 1995. Bloom of the Oscillatoria (Trichodesmium) erythraea (Ehrenberg) Kutz in coastal waters of southwest Atlantic. Publção Esp. Inst. Oceanograf., São Paulo, 11:133-140

Grant, J. 1988. Intertidal bedforms, sediment transport, and stabilization by benthic microalgae. In: Boer, P. L.; van Gelder, A. \& Nio, S. D. eds. Tide-influenced sedimentary environments and facies. Holland, D. Reidel Publ. Co., p. 499-510.
Hopkinson, C. S.; Fallon, R. D.; Jansson, B. \& Schubauer, J. P. 1991. Community metabolism and nutrient cycling at Gray's Reef, a hard bottom habitat in the Georgia Bight. Mar. Ecol. Prog. Ser., 73:105-120.

Krejci, M. \& Lowe, R. 1987. Spatial and temporal variation of epipsammic diatoms in a spring-fed brook. J. Phycol., 23:585-590

Marone, E. \& Camargo, R. 1994. Marés meteorológicas no litoral do Estado do Paraná: o evento de 18 de agosto de 1993. Nerítica, 8:73-85.

Marone, E.; Camargo, R.; Prata, V. P. J. \& Klingenfuss, M. 1994. Relatório de campanha de medições físicas: Ilha dos Currais 10-17 janeiro/1994. In: Proposta para categoria e o plano de manejo das ilhas oceânicas do litoral do Paraná. Centro de Estudos do Mar, UFPR. $125 \mathrm{p}$.

MacIntyre, H. L.; Geider, R. J. \& Miller, D. C. 1996. Microphytobenthos: The ecological role of the "Secret Garden" of unvegetated, shallow-water marine habitats. I. Distribution, abundance and primary production. Estuaries, 19:186-201.

Muschenchein, D. K. \& Newell, C. R. 1992. Utilization of seston flux over a mussel bed. Mar. Ecol. Progr. Ser., 85:131-136.

Nelson, J. R.; Eckman, J. E.; Robertson, C. Y.; Marinelli, R. L. \& Jahnke, R. A. 1999. Benthic microalgal biomass and irradiance at the sea floor on the continental shelf of the South Atlantic Bight: Spatial and temporal variability and storm effects. Continent. Shelf Res., 19(4):477-505.

Nilsson, C. \& Sundback, K. 1991. Growth and nutrient uptake studied in sand-agar microphytobenthic communities. J. Exp. Mar. Biol. Ecol., 153:207-226.

Nilsson, P.; Jonsson, B.; Swanberg, I. L. \& Sundback, K. 1991. Response of a marine shallow-water sediment system to an increasing load of inorganic nutrients. Mar. Ecol. Prog. Ser., 71:275-290.

Peterson, B. J. \& Howarth, R. W. 1987. Sulfur, Carbon, and Nitrogen isotopes used to trace organic matter flow in the saltmarsh estuaries of Sapelo Island, Georgia. Limnol. Oceanogr., 32:1195-1213.

Pezzuto, P. \& Borzone, C. 1997. Relatórios dos cruzeiros do projeto Vieira. Cruzeiros II (15-17 março de 1996) e III (20-22 abril de 1996). Notas Técnicas da FACIMAR, $1: 81-88$.

Pinckney, J. \& Zingmark, R. G. 1991. Effects of tidal stage and sun angles on intertidal benthic microalgal productivity. Mar. Ecol. Prog. Ser., 76:81-89.

Pinckney, J. \& Zingmark, R. G. 1993. Biomass and production of benthic microalgal communities in estuarine habitats. Estuaries, 16:887-897.

Schreiber, R. A. \& Pennock, J. R. 1995. The relative contribution of benthic microalgae to total microalgal production in a shallow sub-tidal estuarine environment. Ophelia, 42:335-352.

Strickland, J. D. H. \& Parsons, T. 1972. A practical handbook of seawater analysis. Bull. Fish. Res. Bd. Can., 122:1172.

Sundback, K. \& Snoeijs, P. 1991. Effects of nutrient enrichment on microalgal community composition in a coastal shallow-water sediment system: an experimental study. Botanica mar., 34:341-358. 
Taylor, F.; McMinn, A. \& Franklin, D. 1997. Distribution of diatoms in surface sdiments of Prydz Bay, Antarctica. Mar. Micropaleont., 32(3-4):209-229.

Utermöhl, H. 1958. Zur Vervollkommnung der quantitativen phytoplankton - Methodik. Mitt int Vertheor. Angew. Limonol., 9:1-38.

Varela, M. \& Penas, E. 1985. Primary production of benthic microalgae in an intertidal sand flat of the Ria de Arosa, NW Spain. Mar. Ecol. Prog. Ser. 25:111-119.

Veiga, F. A.; Angulo, R. J.; Marone, E.; Brandini, F. P. \& Carrilho, J. C. 2003. Medidas de velocidade de corrente e vazão na plataforma continental interna paranaense utilizando perfilador de corrente acústico Doppler ADCP. In: Congresso da Associação Brasileira de Estudos do Quaternário, 9. Recife, 2003. Resumo Expandido, Recife, ABEQUA/ABRH/INQUA/IPRH, 2003. CD-Room.

\section{Sources of Unpublished Material}

Abrahão, R. L. B. E. 2000. Variabilidade diária do zooplâncton e de descritores ambientais no setor euhalino da Baía de Paranaguá no verão e inverno de 1996. Dissertação de Mestrado, Departamento de Zoologia, Universidade Federal do Paraná, 65p.

Queiroz, R. L. 2002. Inorganic nitrogen uptake kinetics by estuarine sediment microalgal communities. Ph.D. Dissertation, Department of Oceanography, Florida State University. $75 \mathrm{p}$.

(Manuscript received 17 March 2004; revised 01 June 2004; accepted 31 August 2004) 